\title{
Electronic-Banking Services: A Study on Selected Commercial Banks in Bangladesh
}

\author{
Md. Motahar Hossain', Dilara Irin², Md. Shajedul Islam³, \& Sumi Saha ${ }^{4}$ \\ ${ }^{1}$ Senior Lecturer, School of Business, University of Information Technology \& Sciences, Bangladesh \\ ${ }^{2}$ Assistant Professor, University of Information Technology \& Sciences, Bangladesh \\ ${ }^{3}$ Lecturer, School of Business, University of Information Technology \& Sciences, Bangladesh \\ ${ }^{4}$ Lecturer, Accounting and Information System, University of Rajshahi, Bangladesh
}

\begin{abstract}
E-Banking as the wave of the future, provides enormous benefits to consumers in terms of cost of transactions, either through internet, telephone or other electronic delivery channels. E-Banking is now widely practiced in Bangladesh. There are various types of e-banking services like SMS banking, Tele Banking, Push and Pull services, ATM, Fast Track etc. that have been introduced by the commercial banks in Bangladesh. This study attempts to explore various forms and characteristics of e-banking and finds out the merits and demerits of e-banking in selected commercial banks of our country. The major findings of the study show that all the commercial banks selected for the study have been practicing e-banking successfully and Dutch-Bangla Bank Ltd. is providing electronic banking services more effectively than other commercial banks selected in this study. Besides, there is a positive impact of e-banking on the socioeconomic development in Bangladesh. There should be diversification of such activities in rural areas of Bangladesh.
\end{abstract}

Key words: E-Banking, ATM, Push and Pull services, and Commercial Banks JEL Classification Code: M15

\section{INTRODUCTION}

$\mathrm{E}$ -Banking or internet banking is the next stage in the development of banking services in Bangladesh. The banking system in the country was known for their stability and also stubbornness. The public banks in the country always resisted to any kind of change in their working styles through strikes and walk outs. But after some vigorous training and negotiations the concept of online banking was brought into mainstream banking in Bangladesh. This was already popular in other developed countries and with the opening up of the banking market to foreign players in Bangladesh. It was begging to be implemented in our mainstream commercial banking systems. E-banking is viewed as the means of providing traditional services in a modern way ${ }^{1}$. Internet banking has been so popular in the countries; it has been implemented in so far due to certain reasons. Online Banking makes the regular transactions for a client speedy and time efficient with little or no paperwork involved. There is no need for standing in long ques any more for making a deposit or getting a withdrawal. Banking has turned into a $24 / 7$ service with the bank always available to their client. This especially helps the various businessmen who need the best services at any time day or night. Online banking is the need of the new professional in this modern age who is always on the move and working and trying to succeed in a constantly changing and dynamic environment. Through online banking the bank can attract the more sophisticated clients whose needs can now be met through the internet. Also this makes the banks competitive in the international market and against the best banks in the world. Online banking has positively affected the banks in increasing their customer diversity and improved the quality of clients as well.

\section{OBJECTIVES}

The major objectives of the study are as follows:

- To analyze the nature of e-banking activities and their characteristics in selected commercial banks in Bangladesh.

- $\quad$ To find out the major benefits and constraints along with their impact on growth and development of commercial banks in Bangladesh.

- To provide necessary suggestions for developing the system.

\section{SigNIFICANCE OF THE STUDY}

E-Banking can conveniently manage all our banking needs 24 hours a day, 7 days a week with online banking. This internet-based solution allows us to manage our business finance from any computer with internet access. Online banking application addresses the needs of small, individual and corporate account holders of the bank. This application provides a comprehensive range of banking services that enable the customer to meet most of their banking requirements over the net ${ }^{2}$. 
Internet banking is very convenient as the advantages far outweigh any disadvantages. There are many different positive aspects to e-banking. One of them is that we can do our banking from home, without having to waste gas driving to the bank or waste time waiting in line. Most banks are eager to get us to try online banking. Check out our banking terms with regard to this option offered by most banks. The history of online banking has always stressed convenience for the customer as well as security. Today, we can not only enjoy secured banking transactions online, but we can have our paycheck automatically deposited into our bank account and have it available that day, instead of waiting until the check clears. In addition to getting automatic deposits, online banking transactions also include automatic bill paying. Instead of having to write a check to pay our bills, we can have the bills that we pay each month automatically deducted from our banking account each month. Internet banking is not just concentrated on our checking account. We can also use internet banking to get a loan. There are some online banks that will offer us every service that a land bank will offer only they exist only online. Some other bank also, most likely, encourages online banking and offers free features such as checking to savings account deposits, automatic bill paying, automatic deposit and home equity loans-all with the click of a mouse. Debt management is essential when structuring our finances. Internet banking is the way of the future. We can bank from our home without having to wait a second-and best of all, online banking is free. With the rapid development of internet, e-commerce and e-banking are ready to play a significant function in the near future in Bangladesh. The innovative opportunities should be reachable by both large and small companies. But the right commercial and legal system is vital for the constructive augmentation of E-commerce in our country, which is the immaturity level. To ensure optimistic impact of E-banking, information structure, cyber laws and skilled manpower along with environmental facilities are immediately needed ${ }^{3}$.

Now-a-days electronic banking is a topic of paramount importance. Exploring the available literature it has been found that no in-depth work has been done on the topic till now. But there is a vital nexus between e- banking and economic development in the present era of globalization. So working on the topic is essential for the greater interest of people. In fact, the work has enormous justification from theoretical and practical view points.

\section{LITERATURE REVIEW}

Mizanur Rahman ${ }^{4}$ finds that in Bangladesh, the expansion of e-banking is beset with several infrastructural, institutional, and regulatory constraints such as inadequate availability of reliable and secure telecommunication infrastructure, absence of a backbone network connecting the whole country, poor ICT penetration in the banking sector, lack of skilled manpower and training facilities, absence of supportive policies, guidelines, rules and regulations relating to etransactions and the like. Despite the constraints, efforts by the Bangladesh Bank in modernizing the country's payment system and commitment by the government in building 'Digital Bangladesh' have brought competition among the scheduled banks to improve banking services and rapidly adopt e-banking on a wider scale. This note provides a critical overview on development of ebanking in Bangladesh and future prospects for better understanding the issue that includes concept of ebanking, present status of scheduled banks in adopting e-banking services, and prospects of e-banking in Bangladesh on the basis of current trend in developing the ICT infrastructure in the country as well as ICT penetration in the banking sector that follows some policy suggestions for Bangladesh Bank, Govt. of Bangladesh and scheduled banks so that optimum benefit through e-banking may be obtained. A well functioning e-banking network dependant on availability of a backbone network is connecting the whole country reliable and secure information infrastructure including telecommunication infrastructure; ICT penetration in the banking sector; skilled operational personnel; and legal and regulatory framework. The government, Bangladesh Bank and scheduled banks are related to these issues. Therefore, both individual and joint efforts are needed to overcome the constraints in promoting e-banking in the country.

Syed Abdulla Al Mamun and Mst. Nusrat Sharmin ${ }^{5}$ had a study on Management Information Systems (MIS) of a Bank. They said that an effective management information system provides users with accurate, timely and relevant information to support organization functions, decision making, communication, coordination, control, analysis and visualization. Thus it provides tremendous economic values of the various industries, particularly banking industry. The study shows that Standard Chartered Bank (SCB) uses computer based MIS in every sphere of its management and operation. It continuously up-to-date its information systems installing real time technology to enhance its operational effectiveness as well as to meet the ever changing customer needs.

The modern computer based management information system of SCB significantly contributes to its tremendous business performance ensuring real time communication in every step of its operation. As a result, SCB, a successful multinational bank operating in Bangladesh, countries to find new and better ways to put technology to its operation and customers' best use. Moreover, it manages the business risks associated with its technology and investment properly. So the findings of the study can be a good lesson for the local banks and other financial institutions to adopt and manage the modern computer based management information systems. 
Shihab Uddin Khan ${ }^{6}$ wrote an article on security aspects of E-banking: Biometric Technology. He found that an appreciation of the factors that securities encompass is important to understand security for electronic banking and related applications. For example, take a simple illustration of Bank Vault, as most would consider a bank vault highly secure. It draws its security from number of factors. The vault is built of strong material and is located in a secure building that offers considerable physical security. Access to the vault is controlled by a sophisticated door and locking mechanism that would require special technical skills and expensive equipment and reasonable time to breach. The physical and technical characteristics of the vault mean that it would take considerable time and resources to breach it. Since both building and vault are protected through automated alarms, attempting to breach the vault carries significant risk of being caught. The likelihood of an attempt on vault is very low. Further, any deposits held in the bank are not actually in the vault so that even if a robbery occurs, there is no loss of the deposits. Thus, the vault has low expected loss. Despite all these factors, from time to time, a bank vault is breached, even then they are widely considered to be secure. Credit card is another such example as most consumers use credit cards and are reasonably comfortable in using these plastic cards. These are considered acceptably secured. The cards and card numbers contain some elements of technical and physical security and few cards contain a picture of the legitimate credit card holder and bear the holder's signature. Credit card companies deploy sophisticated mechanisms such as analyzing spending patterns to detect fraud. While forging a single credit card may not require much of the organization's resources, forging and using many cards which may generate a large loss require considerable resources. The credit card holder is protected from loss by laws which limit the holder's financial obligation losses. Credit card fraud is widespread and a card issuer is certain to encounter fraud, even though the instance of fraud is low compared to the total number of transactions. From a user's perspective, there are so many cards with widespread use that the likelihood of an individual encountering a problem is very small. Further, the lack of data and message security on the Internet has also become a serious problem due to the increasing number of merchants trying to spur commerce on the global network. For instance, credit card numbers in their plain text form, create a risk when transmitted across the Internet where the possibility of the number falling into the wrong hands is relatively high. Just the thought of "sniffer" programs which collect credit card numbers, en masse, is enough to keep merchants away from on-line shopping. In short, the lack of business transaction security is widely acknowledged as a major impediment to spread e-commerce. Historically, computer security was provided by the use of account passwords and limited physical access to a facility to bonafide users. As users began to dial in from their PCs and terminals at home, these measures are being considered insufficient. With the advent of remote users on inter-networks for conducting commercial transactions on mobile computers and through wireless technologies, simple password schemes are not sufficient to prevent attacks from sophisticated hackers. However, there are certain peculiarities to the issue of security. The first issue is that security is never absolute. The bank vault though can be breached but is still considered secured.

The second peculiarity of security is that there is an economic trade-off among the cost of security, expectation of loss, and the cost of breaching security. From the perspective of an organization, a taka spent on security is justified when it reduces the expected loss by more than the same amount. When security spending reaches the point where the cost of additional security exceeds the incremental loss reduction, then it offers no more value protection and security is considered adequate. From other perspective, security is adequate when the expected yield is less than the cost of breaching security. For rational asset holders and opponents, the notions are equivalent. The characteristics that define security are two viz. securities are never absolute and security adequacy is an economic decision.

\section{Methodology}

The study consists of selection of sample, nature and sources of data, collection of data and characteristics of analysis followed:

Sample Selection: Sample of the study includes four commercial banks like Dutch-Bangla Bank Ltd., Mercantile Bank Ltd., Islami Bank Bangladesh Ltd. and BRAC Bank Ltd. Banks are selected on the basis of availability of data and convenience in data collection.

Nature and sources of data: The study is based mainly on secondary data like annual reports of the selected commercial banks, relevant research studies done earlier, and publications of Bangladesh Bank.

Major characteristics of analysis: The following aspects of information are highlighted:

1. Various forms of E-Banking like SMS banking, Tele banking, ATM, Internet banking etc.

2. Benefits and constraints of E-Banking such as mobile banking, fast track, ATM services and the absence of 'touch feel' factor, lack of skills and training, cultural changes etc.

3. Different services provided by the commercial banks like cash withdrawal, bill payment, quick fund transfer etc. through automated system.

4. Managerial performance such as equipping human resources, central MIS, automated clearing house etc. 


\section{MAJOR FINDINGS}

Now-a-days State owned commercial banks (SCB), Private commercial banks (PCBs) and foreign commercial banks (FCBs) follow modern technology in e-banking services. The significant features of such services are as follows:

Automated Teller Machine (ATM): An automated teller machine (ATM), also known as a automated banking machine (ABM) or Cash Machine and is a computerized telecommunications device that provides the clients of a financial institution with access to financial transactions in a public space without the assistance of bank's cashier or bank teller. In most of the modern ATMs, the customer is identified by inserting a plastic card which is known as ATM card with a magnetic stripe or a plastics smart card with a chip, that contains a unique card number and some security information such as an expiration date etc. Authentication is provided by the customer entering a personal identification number (PIN). Using an ATM, customers can access their bank accounts in order to make cash withdrawals, credit card cash advances, and check their account balances as well as purchase prepaid cell phone credit. If the currency being withdrawn from the ATM is different from that which the bank account is denominated in (e.g.: Withdrawing Japanese Yen from a bank account containing US Dollars), the money will be converted at a wholesale exchange rate, Thus, ATMs often provide the best Possible exchange rate for foreign travelers and are heavily used for this purpose as well ${ }^{7}$.

SMS Banking: SMS Banking is a service that allows customers to access their account information via mobile phone. SMS Banking services are operated using both push and pull messages. Push messages are those that the bank chooses to send out to a customer's mobile phone, without the customer initiating a request for the information. Pull messages are those that are initiated by the customer, using a mobile phone, for obtaining information or performing a transaction in the bank account. Customers who maintain an account, with its bank, can have access to internet banking facility provided by that bank. But he/she has to enroll for these services. Usually, the common services like Account balance Inquiry, Transaction Inquiry, Cheque status Inquiry, Password Change, Transfer fund between own accounts within the bank, Mini Statement, Requisition for cheque book etc. being provided by SMS Banking.

PUSH \& PULL Services: Push messages are those that the bank chooses to send out to a customer's mobile phone, without the customer initiating a request for the information. Typically push messages could be either mobile marketing messages or messages alerting an event which happens in the customer's bank account, such as a large withdrawal of funds from the ATM or a large payment using the customer's credit card etc. Another type of push message is One Time Password
(OTPs). OTPs are the latest tool used by financial and banking service providers in the fight against cyber fraud. Instead of relying on traditional memorized passwords, OTPs are requested by consumers each time they want to perform transactions using the online or mobile banking interface. When the request is received the password is sent to the consumer's phone via SMS. The password is expired once it has been used or once its scheduled life-cycle has expired.

Pull messages are those that are initiated by the customer, using a mobile phone, for obtaining information or performing a transaction in the bank account. Examples of pull messages for information include an account balance enquiry, or requests for current information like currency exchange rates and deposit interest rates, as published and updated by the bank. The bank's customer is empowered with the capability to select the list of activities (or alerts) that he/she needs to be informed. This functionality to choose activities can be done either by integrating to the internet banking channel or through the bank's customer service call centre.

Typical push and pull services offered under SMS Banking: Depending on the selected extent of SMS banking transactions offered by the bank, a customer can be authorized to carry out either non-financial transactions, or both financial and non-financial transactions. SMS banking solutions offer customers a range of functionality, classified by push and pull services. Typical push services would include - Periodic account balance reporting, Reporting of salary and other credits to the bank account, Successful or un-successful execution of a standing order, Successful payment of a cheque issued on the account, Insufficient funds, Large value withdrawals on an account, Large value withdrawals on the ATM or EFTPOS on a debit card, Large value payment on a credit card or out of country activity on a credit card and One time password and authentication. On the other hand typical pull services include - Account balance enquiry, Mini statement request, Electronic bill payment, Transfers between customer's own accounts, like moving money from a savings account to a current account to fund a cheque, Stop payment instruction on a cheque, Requesting for an ATM card or credit card to be suspended, Dc-activating a credit or debit card when it is lost or the PIN is known to be compromised, Foreign currency exchange rates enquiry and Fixed deposit interest rates enquiry.

There is a very real possibility for fraud when SMS banking is involved, as SMS uses insecure encryption and is easily spoof able supporters of SMS banking claim that while SMS banking is not as secure as other conventional banking channels, like the ATM and internet banking, the SMS banking channel is not intended to be used for very highrisk transactions. 
Technologies employed for SMS banking: Most SMS banking solutions are add-on products and work with the bank's existing host systems deployed in its computer and communications environment. As most banks have multiple backend hosts, the more advanced SMS banking systems are built to be able to work in a multi-host banking environment; and to have open interfaces which allow for messaging between existing banking host systems using industry or de-facto standards. Well developed and mature SMS banking software solutions normally provide a robust control environment and a flexible and scalable operating environment. These solutions are able to connect seamlessly to multiple SMSC operators in the country of operation. Depending on the volume of messages that are required to be pushed, means to connect to the SMSC could be different, such as using simple modems or connecting over leased line using low level communication protocols (like SMPP, UCP etc.). Advanced SMS banking solutions also cater to providing failover mechanisms and least-cost routing options.

Tele-banking: Tele-banking is a form of remote banking which is essentially the delivery of branch financial services via telecommunication devices where the bank customer can perform retail transactions by dialing a touch-tone telephone or mobile communication unit, which is connected to an automated system of the bank by utilizing Automated Voice Response (AVR) technology. Tele-banking has been introduced in Bangladesh since 1990s. The use of Tele- banking is easy and confidential. All you need is a push button telephone, your account number, and Personal Identification Number (PIN), which you select on your first call and can change at any time. Tele-banking provides services like Checking account balance, Interest rates related information etc ${ }^{8}$.

\section{BanK WISE Scenarios of E-bankING SeRVICES}

Dutch-Bangla Bank Limited is running in its $15^{\text {th }}$ year of operation in the country with a countrywide branch network of 126 branches and nearly 1.5 million customers. It has setup country's largest ATM network comprising of more than 2200 ATMs at the end of 2012. DBBL has Introduced Fast Tracks for the first time in the country to ensure better and wider range of services to the customer. Within six months, the number of Fast Tracks has reached at 50. DBBL has also launched the first ever e-payment gateway of the country which is expected to bring a change in the online purchase and other services dramatically. All these have been possible with the help of a well-trained, highly professional work force and a strong IT infrastructure. To run all the services smoothly DBBL has invested a substantial amount in developing its IT backbone.

Upgradation of Core Banking Software: The truly online core banking software, Flexcube has been running since 2004. In the meantime, the number of customers, accounts, ATMs, Point of Sales (POS) terminals and cards has increased significantly. To ensure better customer service, the bank is upgrading its core banking software from its present version to Flexcube Universal Banking Solution (UBS). In parallel, the whole setup of hardware is being upgraded to cope with the increased volume of transactions from different delivery channels. The core team formed in this regard is working daynight in configuring \& testing of the new system which is expected to go live soon.

Upgradation of Switching Software: A remarkable percentage of transactions of DBBL are performed using the most popular delivery channel ATM. As such, it is equally important to have strong switching software to handle different types of transactions as well as high volume of transactions. Considering this, the bank is upgrading its switching software too. The upgraded software will not only ensure better and quick response to the requested transactions, it will also be capable to handle EMV transactions. All the ATMs and POS terminals of DBBL are EMV-compliant. The EMV security policy has been introduced by Europay, MasterCard and VISA jointly to protect capturing card data and duplication of a card. DBBL has introduced BMV compliant chip based Mastercard cards and VISA Cards for the first time in Bangladesh which is the most secure card in the world. The ATM/POS networks of the DBBL are also EMV compliant and accept the cards like EMV compliant chip cards of all the banks in the world, Non-EMV Visa \& MasterCard cards of banks in the world and DBBL's proprietary cards (Nexus).

DBBL has put its level of innovation and standard of customer support to a new height by setting another milestone in the history of banking sector by adding two units of Mobile ATM booths to its existing ATM network. DBBL has become the first bank in the country to provide such unique service and convenience to the customers.

Mobile Banking: Around $87 \%$ of the total population of Bangladesh is un-banked. To bring such a huge population into the banking channel, DBBL is implementing a system of mobile banking successfully. With this facility any person having a mobile number is able to use his number as a bank account. In this mobile account customers can get the services like Cash deposit to any Agent of DBBL, Cash withdrawal from any Agent of DBBL, Cash withdrawal from DBBL ATMs, Funds transfer to another mobile account, Utility bill payment, Tuition fee payment, Air time top-up, Receive remittance from home and abroad, Salary disbursement, Disbursement of Govt. allowances, Merchant Payment and Balance Inquiry.

Automated Teller Machine (ATM): DBBL has the largest ATM network in the country. As on 31st December, 2010, they have installed 1100 (eleven 
hundred) ATMs throughout the country. Customers get various types of services in these ATM booths like Cash Withdrawal, Balance Inquiry, PIN Change, Funds transfer (within accounts), Mini statement, Cheque Book Request, Statement Request, and Bill Payment for different credit cards, Electricity Bill etc.

Customers of other Banks can enjoy the DBBL ATM facilities with some conditions. Eighteen other banks are connected with DBBL ATMs like Southeast Bank, The City Bank, United Commercial Bank, Standard Bank, Mercantile Bank etc. In the month of December, 2010 the total number of Cash withdrawal from ATMs was 230 million and the corresponding amount of withdrawal was Taka 13.20 billion.

Fast Track: To provide uninterrupted quick and faster service, the bank has introduced Fast Tracks (FT) in the country. These FTs are comprised of several ATMs, Deposit Kiosks and Customer Service help desk officers. The customers have the facility to deposit cash or cheque, withdraw cash, pay utility bills etc. at the FT. DBBL has setup 50 FTs within 6 months of introducing it. The major activities of FT are summarized below:

Cash Withdrawal: Customers can withdraw money from any of the $6-10$ units of ATMs installed at FT. The ATMs are powered from different UPS and linked to Data Center through various link providers which created redundancy for power failure and network problem. Again due to multiple ATMs at FT, further redundancy has been ensured for ATM disorder. Cash shortage and Cash jam. These ensure that a customer will be able to withdraw money from ATM at FT without failure. On the other hand, presence of an officer at FT helps the customer to solve any ATM related problem such as Cash/Card capture?.

Islami Bank Bangladesh Limited is operating its banking operations through electronic network and performing the following services successfully:

Working Paradigm of ICT of IBBL: To accelerate customer service and to offer new products through embracing innovative technologies and ideas, IBBL has always been a front runner. It has always used these products and services to make banking easier \& simpler and to make the Bank totally IT driven through full automation. To list a few of the achievements, the Bank has online connectivity to its all branches having dual connectivity at all major \& city branches, which is the largest online banking network amongst all Banks. Its Data Centre is the largest in the Banking sector of the country. Remittance Card is already available for beneficiaries of foreign remittance earners and the Bank will very soon introduce its own Islamic Credit Card (Khidmah Card) \& different Pre-Paid Cards along with existing ATM (debit) Card.

Core Banking System of IBBL-eIBS (Electronic Integrated Banking System): IBBL is the first and only
Bank in Bangladesh to possess in-house developed, fully fledged Core Banking System-elBS. It is based on open source technologies and most secure Database Management System, ORACLE. All banking modules have been fully integrated in elBS running at all branches including SME branches and Rural Development Scheme (RDS).

Online Banking: Presently, IBBL possesses the largest online banking network in the country. All branches including Agriculture Branches are under online connectivity using Fibre Optics and Radio Links with 117 branches having dual connectivity to provide seamless 'Any Branch Banking' to the clients. On an average, nearly 23000 transactions; per day are now performed by the Branches with volume of approx. Tk.500 crores using on line remote deposits and withdrawals.

ATM network with other ATM networks: Since 2001, IBBL started for providing ATM service to its customers from 55 branches through a consortium of financial organizations using $3^{\text {rd }}$ party ATM service provider. On an average, nearly 10,000 transactions with withdrawal of more than Tk.7 crores are now done per day. Remittance Card has been rolled out into service. Customers now can perform full or partial withdrawal of their foreign remittance amount either from IBBL ATMs or branches using Remittance Card. After joining world's largest retail electronic payment network-VISA as a principal member last year, the Bank is now focusing to rollout VISA enabled debit cards and Shari'ah complaint Credit Card (Khidmah) which can be used at any global e-outlets (ATMs and POS).

Online Data Centre (DC) \& Disaster Recovery Site: IBBL has the country's largest Data Centre in the Banking sector running on Sun Solaris 10 and Oracle $10 \mathrm{~g}$ Enterprise Edition wherein Branch data are uploaded incrementally from all the branches. These data are used as backup for emergency situations \& MIS report preparation for different Wings/Divisions/Departments of Head Office. Currently, the DC setup is being extended to incorporate new systems, hardware and other components. Restructuring of the existing WAN architecture is going on as well with provision of 'automatic failover' which will automatically connect a branch to the IBBL WAN using alternative connectivity in case the default one goes offline. IBBL has a Disaster Recovery Site (DRS) at a separate place as per the guideline of Bangladesh Bank which acts as a replication establishment of the bank's existing Data Center.

Internet Banking (iBanking) and SMS Banking: For past couple of years, IBBL put emphasis on alternate delivery channels like iBanking and SMS Banking to take banking services to the doorsteps of the customers and started some related services. Now, the Bank offers a range of Internet Banking (iBanking) \& SMS Banking Services to its customers. 
Equipping Human Resources: IBBL, by now, has accomplished the vision of 'one man one computer' status. The total workforce of the Bank is now equipped with computer. And whenever new recruits are engaged in service, they are being provided with computers as per requisition.

Central MIS: IBBL has built a strong Central MIS for the Bank. It now contains necessary information (i.e. Branch Accounts \& General Ledger (GL) related, Zone level, Central level information) for perusal of the Management \& other bodies including Internal Control \& Compliance Wing, Shari'ah Secretariat and Zonal offices for supervising and monitoring related issues.

BACH (Bangladesh Automated Clearing House): IBBL has developed a system (as per guidelines of Bangladesh Bank) required for $\mathrm{BACH}$ operations. Through its implementation, same day clearing of instruments is now possible. The System has been deployed to 77 branches of IBBL that have BACPS (BACH) in operation.

BEFTN (Bangladesh Electronic Fund Transfer Network): IBBL has been one of the few banks to develop own BEFTN system as per guidelines of Bangladesh Bank. Now, all branches of IBBL are capable of sending and receiving electronic funds through BEFTN. Everyday huge amount of third bank remittance and dividend/refund warrant are paid using this system which is also capable of providing person to person (P2P), business to business (B2B), and person to business (P2B) payments.

BRAC Bank Limited is one of the pioneers in electronic banking service provider in Bangladesh. The bank has begun its operations since July 4, 2001. At present the bank has 86 braches, 70 SME service centers, 140 zonal offices and 400 unit offices of SME. The primary objectives of the bank are to carry out on all kinds of banking businesses. BRAC Bank provides the following services through internet.

SMS Banking: BRAC Bank is providing banking services through mobile SMS. The services includeInstant Account balance \& mini statement, Fixed deposit maturity alarm, High value transaction alert, Accounts status charging alert, Welcome alert (for account opening), Payment (loan) failure alert and Cheque clearing failure alert etc. The benefits of SMS banking are as follows:

Simple \& Convenient: With SMS Banking, the bank sends statement to a customer by mail through internet. Once a customer becomes a member of SMS Banking, he/she will have 24-hours access to the key financial information of his/her account.

Push \& Pull: Through BRAC Bank SMS Banking, customers will be able to access their account's current information like balance, last few transactions and a range of other financial information. These services

Copyright (C) 2013, Asian Business Consortium | ABR available for GrameenPhone, Banglalink, Warid and AKTEL subscribers.

Easy to Apply: To sign up for SMS Banking, all the prospective customers need to fill-out the enclosed form and submit it to their nearest branch.

Phishing: Phishing is the process of collecting User Name / Account Number / Account Details / Credit Card No / Expiry Date / Pin / Password and other sensitive financial information over the Internet with malicious intent. Fraudsters tries to disguise themselves as genuine company and sends e-mail, Pop Ups, Instant message to clients of financial service providers. They request clients to provide them with various crucial account information promising a better service, free gifts or promotional activities. As soon as information entered in these link web sites they are stored and used for fraudulent purpose by the hackers ${ }^{11}$.

Mercantile Bank Limited emerged as a new commercial bank to provide efficient banking services and to contribute socio-economic development of the country. The Bank commenced its operation on June 2, 1999. The Bank provides a broad range of financial services to its customers and corporate clients. The Board of Directors consists of eminent personalities from the realm of commerce and industries of the country. The bank is operating with 86 branches through countrywide. It has set up 100 ATM network to provide better customer services. The following e-banking services are practicing by the bank.

Online Banking: Online Banking has been activated in all Branches of the Bank from January 01, 2006. Online service is now available for all customers - Both Cash deposit and withdrawals, Cheque Deposits and Transfer in CD, SB, STD, Loan accounts (Cheque Bearing within limit) and Monthly Savings Scheme (MSS).

Mobile Banking: Like in many other countries, people in Bangladesh started believing in mobile banking. With the approval of Bangladesh Bank, MBL is going very speedy to introduce mobile banking throughout the country. In Mobile Banking system, basic mobile handsets are being used as bank accounts and will serve as a wallet for the transaction of money, especially for the un-banked people. As 99 percent of the people of Bangladesh are under the mobile phone network, almost all will have access to the formal financial channel. If the banks can reach out to the un-banked people, the dream of more people having bank accounts can be fulfilled. For successful launching of the mobile financial services, MBL has renovated its Card Division and renamed it as "Card and Mobile Banking Division". A Mobile Banking Team is working under the "Card and Mobile Banking Division" to successful initiation of Mobile Banking Service.

SMS Banking: With the passage of time, life style undergoes changes. To keep pace with changes, MBL 
encourages to SMS Banking Service regarded as one of the most up-to-date banking services in Bangladesh. SMS banking service is convenient, safer, cheap and faster. One can access it at any time. MBL's SMS banking service offers services such as Access to account balance, Last 3 transaction inquiry, Cheque status inquiry, etc ${ }^{12}$.

\section{BENEFITS OF E-BANKING}

E-banking is now a global phenomenon. Apart from the developed countries, the developing countries are experiencing strong growth in e-banking. Internet banking in South Korea has increased at a rapid pace. South Korea is also leading in online brokerage and mobile banking. In Southeast Asia, internet banking is also developing rapidly in Thailand, Malaysia, and Singapore and to a lesser extent in the Philippines. In Nepal, ATMs are the most popular electronic delivery channel for banking services but only a few customers are using internet banking facilities. Among others, Nepal's commercial banks have adopted credit card, telebanking, and SMS-banking.

With the increasing popularity of the internet, more and more industries are seeking ways to utilize this popular medium in an effort to keep up with the changing technological preferences of their customers. These days we can do just about anything online from grocery shopping to making a free phone call to a friend in Tokyo through our PC. The possibilities of the internet are seemingly endless and the banking industry has decided that it will not be left behind. While most people have at least heard of online banking, the majority of them have probably not tried it yet. Maybe it's because we find more comfort in working with real people and real paper when it comes to money matters rather than performing transactions in the seemingly impersonal universe of the World Wide Web. Whatever the case may be, there are both advantages and disadvantages to online banking. This article will outline these advantages and disadvantages so you can either feel justified in your fears or see online banking as a safe way to quickly and efficiently manage your finances ${ }^{13}$.

First, online banking is convenient. It allows you to perform transactions, pay bills and check balances 24 hours a day, 7 days a week. The bank virtually never closes because it is as accessible as our PC or laptop computer. No matter where we are in the country or in the world, we can visit our online bank and handle money matters. We can even schedule to pay several payees ahead of time rather than keeping up with paper bills or trying to remember when to visit a payee's web site to make an online payment. Our bank will automatically send the payments on our behalf in the amounts and on the dates specified.

Second, online banking is fast, efficient and effective. Through the internet, transactions are typically performed and executed at a faster rate than ATM's. In addition, online banks give you the ability to handle several bank accounts (checking, savings, CDs, IRAs, etc.) from one site. The majority of banking sites are also compatible with programs like Quicken and Microsoft Money, so as to allow for more effective management of assets.

\section{LIMITATIONS OF E-BANKING}

The main issue for most people is that of trust. We may wonder if our transaction went through successfully or if we clicked on the correct button. The best way to overcome this uneasiness is to make a habit of printing the transaction receipt. Keep this receipt until our bank statement or online account view confirms that we have successfully executed the transaction. Online banking sites can also take a while to start up and can be difficult to learn at first. Some banks require customers to provide some form of photo identification in addition to signing a form at one of their branches. Spouses may also have to sign a power of attorney if we both plan to access and handle our accounts together online. In addition to all of this, it may take a while to learn how to use our banking site. Most if not all banks will offer an online banking tutorial. Some even offer live customer support for online banking via chat, email, or phone. Clearly, online banking has both advantages and disadvantages. It simplifies life for some people and for them it is frankly a better way to bank. For others it may be a little more complex and downright intimidating. In light of these two perceptions, more and more banks are offering online banking as a viable option for their customers. Some constraints of E- Banking are stated below:

- The absence of 'touch-feel' factor: This is the primary obstacle of E-banking. Companies especially, that sell perishable foods and high cost items such as jewelry, antiques may never lend themselves to Ebanking. It may be impossible to inspect these items adequately from a remote location.

- Buyers are shaky to give their credit card detail: Consumers are still somewhat fearful of sending their credit card number over the net. As there is no personal contact between the buyers and sellers, it is difficult to establish trust.

- Small banks are unprepared for global selling: To create a website, maintain it and process orders through net is not possible for all banks especially for those who are undersized.

- The calculation of ROI (Return on Investment) is very difficult: Because technology is changing rapidly and so cost can change dramatically from initial measurement.

- Lack of skill and training: These two factors can impend the implementation of E-banking in banking sector of our country.

- Lack of proper commercial and legal system: Security, lack of apposite and secure payment structures and legal issues are the main concerns. 
- Cultural changes: The E-banking team mostly consists of young and tech savvy people, who may be in direct conflict with the old-timers of the company.

- Intricate to transfer to a new database system: Difficult to integrate the existing database and transaction processing software designed for traditional commerce to a software that enables Ebanking ${ }^{14}$.

\section{SUGGESTIONS}

In order to cope with the changing world the commercial banks have to implement electronic banking system in lieu of traditional banking system. The banking sector of Bangladesh should practice e-banking to accelerate the pace of development in the banking system in order to satisfy the customers demand in time. To provide sophisticated banking services, the commercial banks should ensure the following aspects:

- Customers' consciousness about the modern technology should be increased significantly.

- The electronic banking infrastructure should be developed with help of fiber optic backbone.

- The banks have to train their staff on electronic banking to sell various products to customers.

- The banks must ensure that their e-banking facilities are protected against external threats like cyber crime.

- Government should provide legal framework for electronic banking so that basic rights, such as customers' privacy, unauthorized withdrawal of fund and customer protection can be taken care of.

- The network connectivity should be developed by the commercial banks.

\section{ConCLUSION}

The government of the People's Republic of Bangladesh has put a lot of emphasis on building digital Bangladesh. E-Banking is one of the most important tools to realize that national goal. At present most of the commercial banks of our country are providing their services through internet, mobile and telephone successfully. This is very much helpful for the economic development of the country. There are various types of services like SMS banking, Tele Banking, Push and Pull services, ATM, Fast Track etc. that have been introduced by the commercial banks in Bangladesh. In this study we found that Dutch-Bangla Bank Ltd., Islami Bank Bangladesh Ltd., BRAC Bank Ltd. and Mercantile Bank Ltd. have been providing their e-banking services successfully. Dutch-Bangla Bank Ltd. is providing electronic banking services more effectively than other commercial banks considered in this study. This way the financial institutions have been playing a vital role to accelerate the pace of development of our country.

\section{REFERENCES}

[1] Khan A R, Bank Management, Ruby publications, Dhaka, P. 290, 2008.

[2] Rose Peter S., Commercial Bank Management, McGraw-Hill, New York, P. 21, 2005.

[3] Efraim Turban et al., Electronic Commerce, Addison Wesley Longman, P. 173, 2006.

[4] Rahman, M., Innovative Technology and Bank Profitability: The Bangladesh Experience, Working paper series, Research Work, Policy Analysis Unit (PAU), Bangladesh Bank, (www.banaladeshbank. org.bd), 2008.

[5] Syed Abdullah Al Mamun and Mst. Nusrat Sharmin, ASA University Review, Center for Socio Economic Research, $3^{\text {rd }}$ Issue, Vol.2, No.2, 2011.

[6] Mia, Rahman and Uddin, E-banking: Evolution, Status and Prospects, The Cost and Management, Vol.35, No.1, PP. 36-48, January-February 2007.

[7] Khan A. R., Op cit, P. 294-295.

[8] Rahman, M. M, E-Banking in Bangladesh: Some Policy Implications, Policy notes, Bangladesh Bank Quarterly, January-March 2009, Bangladesh Bank.

[9] Dutch-Bangla Bank Limited, Annual Report, 2011.

[10] Islami Bank Bangladesh Limited, Annual Report, 2011.

[11] BRAC Bank Limited, Annual Report, 2011.

[12] Mercantile Bank limited, Annual Report, 2011.

[13] www.wikipidia.com

[14] Ali, Md. Moktar et.al, Journal of Marketing, University of Dhaka, Vol. 10, June 2007. 
